\title{
Glaucescin, a Bacteriocin-like Substance from Streptomyces glaucescens
}

\author{
By W. SCHURTER, MONIQUE KISSLING-ABDERHALDEN \\ AND TH. LEISINGER \\ Mikrobiologisches Institut, Eidgenössische Technische Hochschule, CH-8092 Zürich, \\ Switzerland
}

(Received 28 November 1978)

\begin{abstract}
Streptomyces glaucescens ETH 22794 produced a variety of antibiotic substances. Besides low molecular weight antibiotics like hydroxystreptomycin and the tetracenomycins, this strain excreted glaucescin, a high molecular weight product with bacteriocin-like properties. In plate tests the antagonism of glaucescin against Streptomyces canadiensis was masked by the large inhibition zone caused by the tetracenomycins. Glaucescin activity was revealed when a tetracenomycin-resistant mutant of $S$. canadiensis NRRL 3155 was used as an indicator. Glaucescin was produced on complex and minimal solid and liquid media. It was not inducible by mitomycin $\mathrm{C}$. The killing activity of glaucescin was thermolabile and resistant to DNAase, RNAase, various proteinases, and lipase. Its apparent molecular weight was estimated as 196000 by gel filtration and glycerol gradient centrifugation. Glaucescin preferentially killed outgrowing spores of $S$. canadiensis. Resting spores and mycelium were considerably less sensitive to the inhibitor, and adsorption of glaucescin by $S$. canadiensis paralleled sensitivity. The activity spectrum of the bacteriocin was restricted to spore-forming Actinomycetales. Non spore-forming nocardiae and a variety of Grampositive and Gram-negative bacteria were resistant to glaucescin.
\end{abstract}

\section{INTRODUCTION}

Production of bacteriocins and bacteriocin-like substances has been observed in various genera of Gram-positive bacteria (for a review, see Tagg et al., 1976). Among the actinomycetes, a group of Gram-positive bacteria known to produce a wide variety of antibiotics, only two antagonistic substances have been described which have the characteristics of bacteriocins. Roelants \& Naudts (1964) reported the production of a mitomycin C-inducible bacteriocin-like substance by Streptomyces virginiae and Franker et al. (1977) characterized a bacteriocin with temperature-dependent killing properties from Actinomyces odontolyticus.

This communication describes some properties of glaucescin, a bacteriocin-like substance of Streptomyces glaucescens ETH 22794. Interest in glaucescin arose in the course of studies on the genetics of extracellular products from this organism because of the possibility that bacteriocinogeny might become useful as a model for plasmid-determined inheritance. At present, however, information on the genetics of glaucescin production is lacking. Streptomyces glaucescens produces hydroxystreptomycin (Hütter, 1967) and the tetracenomycins (Weber et al., 1979), a family of low molecular weight lipophilic antibiotics. Genetic analysis of $S$. glaucescens revealed a circular linkage map (Baumann et al., 1974) and suggested plasmid involvement in the control of melanin formation (Baumann \& Kocher, 1976). 


\section{METHODS}

Organisms. Glaucescin production was studied in strain GLA0, the wild-type of Streptomyces glaucescens ETH 22794. Strain GLA108 is a spontaneous mutant derived from strain GLA0 producing neither hydroxystreptomycin, tetracenomycin C nor glaucescin. Strain GLA600, which is also a spontaneous mutant of strain GLA0, has lost the ability to produce tetracenomycin C. Strain CAN0, the wild-type strain of Streptomyces canadiensis NRRL 3155, was the standard indicator strain used for assaying glaucescin. Strain CAN1, a spontaneous mutant of strain CAN0, is resistant to glaucescin. Strain CAN2 arose spontaneously from strain CAN0 and is resistant to the tetracenomycins. Bacterial strains used for testing the activity spectrum of glaucescin are listed in Table 1.

Media and maintenance of strains. Yeast extract/malt extract agar of Pridham et al. (1957) supported good growth and sporulation of S. glaucescens strains. Glycerol/asparagine agar of Pridham \& Lyons (1961) was used for the propagation of strains of S. canadiensis. Both organisms were stored on slants of these media at $4^{\circ} \mathrm{C}$. The different actinomycete strains used for testing the activity spectrum of glaucescin were grown either on yeast extract/malt extract agar or on glycerol/asparagine agar. The other bacteria used for testing the activity spectrum were all grown on nutrient/yeast agar, which contained $(\%$, w/v): nutrient broth, $0 \cdot 8$; yeast extract, $0.5 ; \mathrm{NaCl}, 0.8$; agar, 2. Endospores of Bacillus species were harvested from cultures grown on GYS broth (Yousten \& Rogoff, 1969). For liquid cultures, S. glaucescens was grown either in the liquid minimal medium of Baumann \& Kocher (1976) or in nutrient/glucose broth, which contained $(\%, w / v)$ : nutrient broth, $0 \cdot 8 ;$ glucose, $0 \cdot 5 ; \mathrm{Ca}\left(\mathrm{NO}_{3}\right)_{2} \cdot 4 \mathrm{H}_{2} \mathrm{O}, 0 \cdot 1(\mathrm{pH} 7 \cdot 3)$. Glucose and $\mathrm{Ca}\left(\mathrm{NO}_{3}\right)_{2}$ were added after autoclaving as sterile $50 \%(\mathrm{w} / \mathrm{v})$ and $10 \%(\mathrm{w} / \mathrm{v})$ solutions, respectively.

Preparation of spore suspensions. Streptomycete spores were scraped from well-sporulated slants or Petri dishes, resuspended in sterile $0.1 \%(\mathrm{w} / \mathrm{v})$ Tween 80 , filtered through cotton wool and centrifuged for $10 \mathrm{~min}$ at $10000 \mathrm{~g}$. The resulting pellet was resuspended in $20 \%(\mathrm{v} / \mathrm{v})$ glycerol and stored at $-20^{\circ} \mathrm{C}$ until used (Hopwood et al., 1973).

Isolation of resistant mutants. Minimum inhibitory concentrations were determined with gradient plates (Szybalsky, 1952) according to the method of Hunt \& Sandham (1969). Mutants of $S$. canadiensis strain CAN0 resistant to the tetracenomycins were isolated on gradient plates containing $5 \mu \mathrm{g}$ tetracenomycin $\mathrm{C} \mathrm{ml}^{-1}$ in the basal layer. Strain CAN2, the mutant isolated by this procedure, showed cross-resistance to the other tetracenomycins.

To isolate glaucescin-resistant strains of $S$. canadiensis, $1.4 \times 10^{4} \mathrm{AU}$ (arbitrary units) glaucescin were incubated with $2.4 \times 10^{8}$ spores of $S$. canadiensis in $9 \mathrm{ml}$ nutrient broth for $1 \mathrm{~h}$ at $4{ }^{\circ} \mathrm{C}$ and subsequently for $2 \mathrm{~h}$ at $30^{\circ} \mathrm{C}$. Portions $(0.5 \mathrm{ml})$ of this mixture were mixed with $2.5 \mathrm{ml}$ yeast extract/malt extract soft agar and overlaid on yeast extract/malt extract agar plates. After $3 \mathrm{~d}$ at $30^{\circ} \mathrm{C}$ a total of 35 well-grown colonies were isolated and tested for glaucescin sensitivity in cross-streaks with strain GLA600. Five of these colonies were not inhibited by strain GLA600. One glaucescin-resistant isolate was designated CAN1 and used in further experiments.

Bioassays for total antibiotic activity and for glaucescin. As will be explained in Results, it is possible to discriminate between the low molecular weight antibiotics produced by $S$. glaucescens and glaucescin by the use of various combinations of producer strains and indicator strains in the bioassay. Qualitative assays for production of antibiotic activities by $S$. glaucescens or for sensitivity of indicator strains to the antibiotic activities produced by $S$. glaucescens were done with deferred cross-streaks. Spores of $S$. glaucescens were streaked with a loop in a single line on a yeast extract/malt extract agar plate and incubated at $30^{\circ} \mathrm{C}$. After 15 to $20 \mathrm{~h}$, spores of $S$. canadiensis were cross-streaked and the plate was incubated further for $24 \mathrm{~h}$.

The quantitative assay for total antibiotic activity of $S$. glaucescens and for glaucescin was based on the critical dilution method (Mayr-Harting et al., 1972). Test samples were sterilized before assaying either by filtration (Sartorius type SM 11336; 0.45 $\mu \mathrm{m}$ pore size) or by addition of a few drops of chloroform. Under sterile conditions twofold serial dilutions in nutrient broth were made with a microtitration system (Dynatech Products). Samples $(10 \mu \mathrm{l})$ of each dilution were spotted with an Eppendorf pipette on indicator plates containing a basal layer of $25 \mathrm{ml}$ yeast extract/malt extract agar and a $3 \mathrm{ml}$ top layer of yeast extract/malt extract soft agar with $10^{7}$ spores of $S$. canadiensis. After $24 \mathrm{~h}$ incubation at $30^{\circ} \mathrm{C}$, the last dilution still giving macroscopically visible growth inhibition was defined as containing 1 arbitrary unit (AU) of glaucescin $\mathrm{ml}^{-1}$. As the dilutions were increased, the inhibition zones did not break up into discrete plaques but became less transparent.

Measurement of growth. Samples $(5 \mathrm{ml})$ from growing cultures were filtered through a glass-fibre filter (Whatman GF/C). The mycelium-coated filters were washed with distilled water and used for protein determinations by the biuret method as described by Herbert et al. (1971).

Preparation of glaucescin. Erlenmeyer flasks (500 ml, with four baffles) containing $150 \mathrm{ml} \mathrm{nutrient/glucose}$ broth or minimal medium were inoculated with spores of strain GLAO from one sporulated slant. The 
flasks were incubated at $30^{\circ} \mathrm{C}$ on a rotary shaker $\left(100 \mathrm{rev} . \mathrm{min}^{-1}\right)$ for $55 \mathrm{~h}$ (nutrient/glucose broth) or for $65 \mathrm{~h}$ (minimal medium). At this stage $0.09 \mathrm{~g}$ (nutrient/glucose broth) or $0.18 \mathrm{~g}$ (minimal medium) wet mycelium were transferred to baffed Erlenmeyer flasks (1 l) containing $300 \mathrm{ml}$ of the medium used for the precultures. During incubation under the conditions described above, samples were taken for growth measurements and glaucescin assays. When maximum glaucescin activity was reached (after $10 \mathrm{~h}$ incubation for nutrient/glucose broth and $35 \mathrm{~h}$ incubation for minimal medium) the mycelium was removed by filtration through a paper filter (Schleicher \& Schuell no. $589^{1}$ ) and the filtrate was used as a crude glaucescin preparation.

A 25 -fold concentration of glaucescin with $100 \%$ recovery was achieved by $\left(\mathrm{NH}_{4}\right)_{2} \mathrm{SO}_{4}$ precipitation at $4{ }^{\circ} \mathrm{C}$. The culture filtrate was mixed with $2 \mathrm{M}$-phosphate buffer $\mathrm{pH} 7.8$ and glycerol to give final concentrations of $0.1 \mathrm{M}$ and $10 \%(\mathrm{v} / \mathrm{v})$, respectively. Solid $\left(\mathrm{NH}_{4}\right)_{2} \mathrm{SO}_{4}$ was slowly added to give $60 \%$ saturation. The resulting suspension was stirred for $1 \mathrm{~h}$ at $4^{\circ} \mathrm{C}$ and centrifuged at $20000 \mathrm{~g}$ for $45 \mathrm{~min}$. The precipitate was dissolved in a small volume of an appropriate buffer, usually $0.1 \mathrm{M}$-phosphate buffer $\mathrm{pH} 7 \cdot 8$ containing $20 \%$ glycerol.

Molecular weight estimations. The molecular weight of glaucescin was estimated by chromatography on a Sepharose CL-6B column $(2.5 \times 88 \mathrm{~cm}$ ). Human haemoglobin A (mol. wt 64150 ; Ganguly et al., 1963), pig heart citrate synthase (mol. wt 100000; Wu \& Yang, 1970), lactic dehydrogenase from rabbit muscle (mol. wt 142000; Jaenicke \& Knof, 1968), pig heart fumarase (mol. wt 194000; Kanarek et al., 1964), catalase from bovine liver (which behaved on columns as a protein of mol. wt 195000; Andrews, 1965) and bovine liver glutamate dehydrogenase (mol. wt 320000; Goldin \& Frieden, 1971) were used to calibrate the column. Glaucescin and the molecular weight markers were applied to the column in a volume of $6 \mathrm{ml}$. Proteins were eluted with $0.1 \mathrm{M}$-phosphate buffer $\mathrm{pH} 7.0$ containing $10 \%$ glycerol at a flow rate of $19 \mathrm{ml} \mathrm{h}^{-1}$ and fractions of $2 \cdot 2 \mathrm{ml}$ were taken from the effluent.

The void volume $V_{0}$ was determined with blue dextran 2000 in a separate run, since a number of proteins (e.g. haemoglobin) are known to bind to blue dextran. Catalase and haemoglobin A were measured by their absorption at $410 \mathrm{~nm}$. The other proteins were assayed by standard methods as described in Bergmeyer (1974).

The sedimentation behaviour was analysed by the technique of Martin \& Ames (1961), using bovine liver catalase $\left(s_{20, \mathrm{w}}=11.30 \mathrm{~S}\right.$; Sober, 1970), fumarase from pig heart $\left(s_{20, \mathrm{w}}=9 \cdot 15 \mathrm{~S} ;\right.$ Kanarek et al., 1964) and human haemoglobin $\mathrm{A}\left(s_{20, \mathrm{w}}=4.56 \mathrm{~S}\right.$; Ganguly et al., 1963) as markers. Samples $(0.3 \mathrm{ml})$ were layered

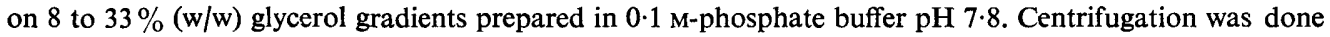
at $4^{\circ} \mathrm{C}$ in a SW50.1 rotor using a Spinco L2-65B ultracentrifuge. After $16 \mathrm{~h}$ centrifugation at $39000 \mathrm{rev}$. $\mathrm{min}^{-1}, 0.15 \mathrm{ml}$ fractions were collected from the bottom of the tubes and analysed for glaucescin and the marker proteins.

Chemicals. Pronase, lactic dehydrogenase (rabbit muscle) and catalase (bovine liver) were purchased from Calbiochem, DNase 1 (beef pancreas), RNase A (bovine pancreas) and mitomycin C from Sigma, and trypsin (bovine pancreas), citrate synthase (pig heart), fumarase (pig heart) and glutamate dehydrogenase (bovine liver) from Boehringer. Proteinase K (mushroom) was obtained from Merck, lipase (Aspergillus rhizopus) from Serva, streptomycin from Novo Industri (Copenhagen, Denmark) and Sepharose CL-6B and blue dextran 2000 from Pharmacia. Ingredients for the complex growth media were purchased from Difco. Tetracenomycin C and human haemoglobin A were generous gifts of W. Weber and H. Zähner (Tübingen) and $\mathrm{K}$. Winterhalter (Zürich), respectively

\section{RESULTS}

\section{Interference of antibiotics with the detection of glaucescin}

Tetracenomycins and hydroxystreptomycin, the lower molecular weight antibiotics produced by $S$. glaucescens, interfered with the qualitative detection of glaucescin in crossstreaks when $S$. canadiensis strain CAN0 was used as an indicator. The minimum inhibitory concentration of streptomycin for strain CAN0 was $0.3 \mu \mathrm{g} \mathrm{ml}^{-1}$ and that of tetracenomycin $\mathrm{C}$ was $0.8 \mu \mathrm{g} \mathrm{ml}^{-1}$. The antibiotic activity of glaucescin produced by strain GLA0 was therefore masked in the cross-streak test by the fast-diffusing tetracenomycins. Glaucescin could be detected when tetracenomycin non-producers, e.g. strain GLA600, were used as a source of glaucescin (Fig. 1). Hydroxystreptomycin was produced in such low amounts that it did not interfere with the test for glaucescin activity.

In order to selectively measure either the low molecular weight antibiotics or glaucescin, we isolated glaucescin-resistant (strain CAN1) and tetracenomycin-resistant (strain CAN2) 

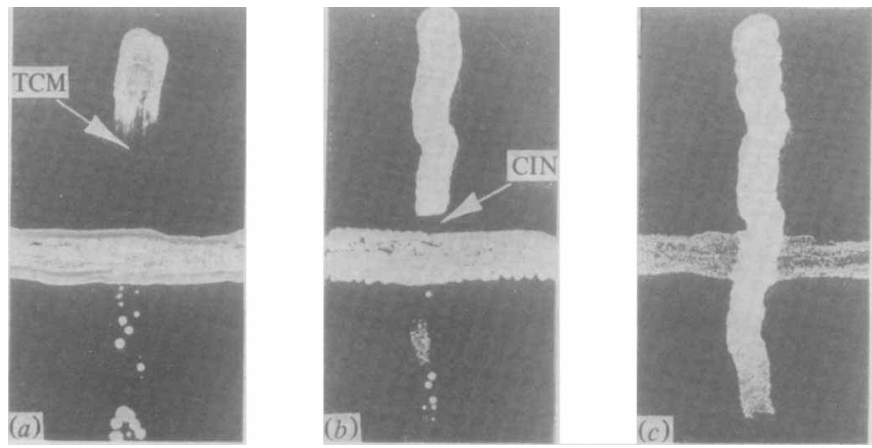

Fig. 1. Deferred cross-streaks of $S$. canadiensis strain CAN0 (vertical streaks) against preincubated horizontal streaks of $S$. glaucescens strains GLA0 (a), GLA600 (b), and GLA108 (c). CIN and TCM indicate the inhibition zones caused by glaucescin and the tetracenomycins, respectively.

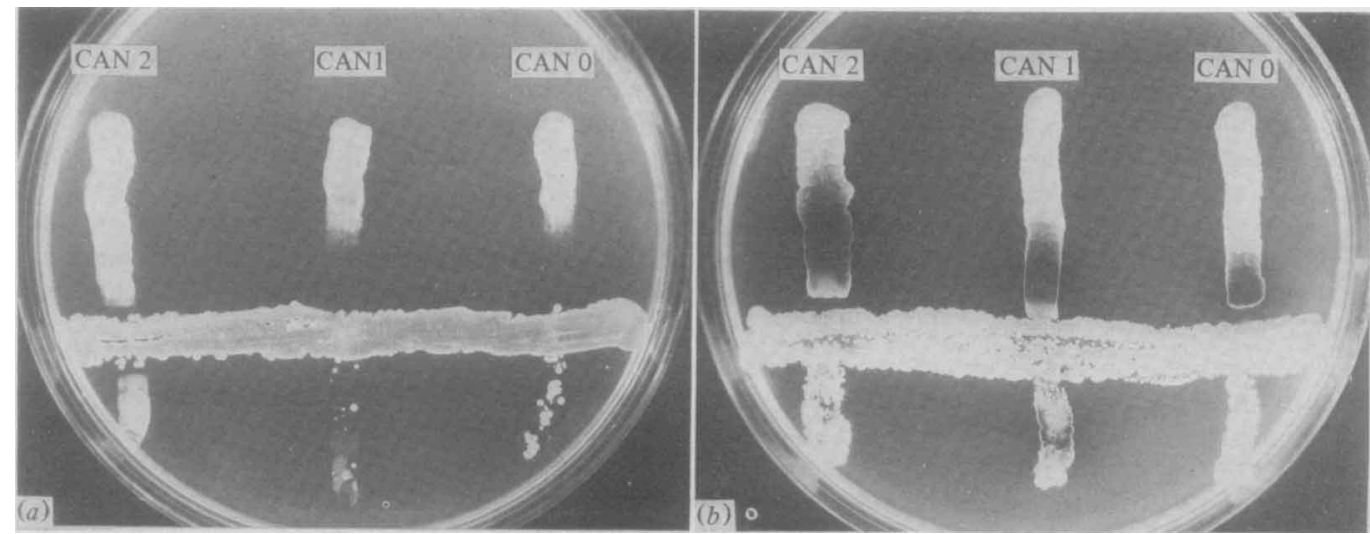

Fig. 2. Deferred cross-streaks of $S$. canadiensis strains CAN2, CAN1, and CAN0 (vertical streaks) against preincubated horizontal streaks of $S$. glaucescens strains GLA0 $(a)$ and GLA600 $(b)$.

mutants of $S$. canadiensis. Strain CAN1 was used to estimate the low molecular weight antibiotics and with strain CAN2 it was possible to assay glaucescin specifically (Fig. 2).

In the quantitative assay for glaucescin by the critical dilution method, the contribution of the low molecular weight antibiotics to the total antibiotic activity was marginal. This is evident from Fig. 3 where glaucescin formation on two media has been followed with strain CANO and with the glaucescin-resistant mutant CAN1 as indicators. In other experiments, the tetracenomycins and hydroxystreptomycin were removed from liquid samples by gel filtration on Sephadex G-25. The wild-type strain CANO was therefore used as the indicator strain for most determinations of glaucescin titres.

\section{Production of glaucescin by $S$. glaucescens}

Glaucescin was produced on different liquid and solid media whereas a bacteriocin from Actinomyces odontolyticus has been reported to be formed only during growth on solid medium (Franker et al., 1977). In early experiments, nutrient/glucose broth was used for cultivating strain GLA0 for $10 \mathrm{~h}$ at $30^{\circ} \mathrm{C}$ which reproducibly led to glaucescin titres of 32 to $64 \mathrm{AU} \mathrm{ml}^{-1}$ (Fig. 3). The correct adjustment of the initial pH of nutrient/glucose broth proved to be crucial for obtaining high glaucescin yields. If the initial $\mathrm{pH}$ of the medium was below $6 \cdot 5$, low yields of glaucescin were obtained. It is not known whether this was due to the instability of glaucescin under acid conditions or whether the formation of glaucescin was decreased during growth on slightly acid media. To avoid some of the 


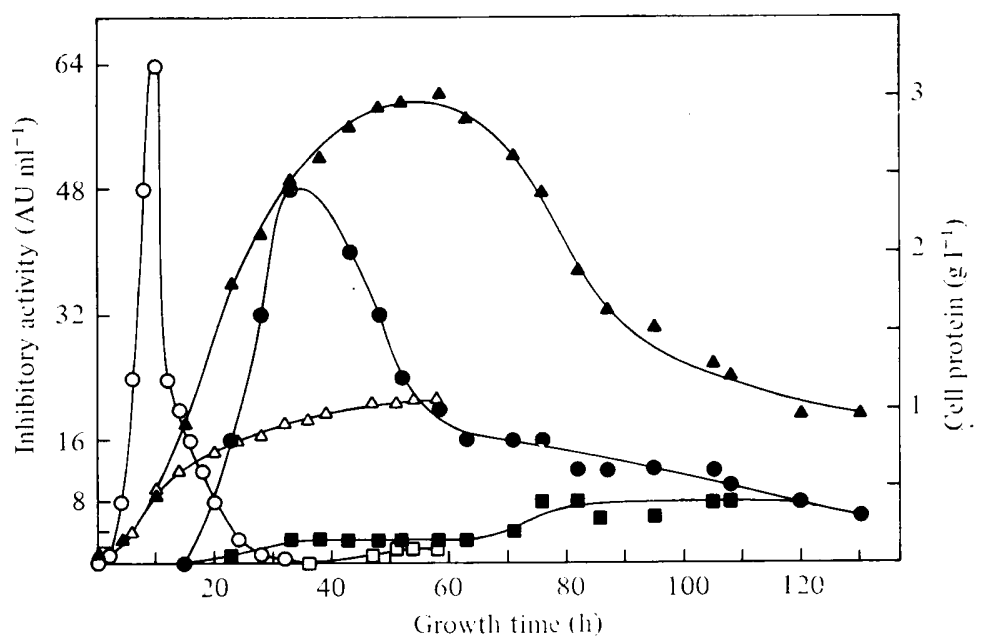

Fig. 3. Production of glaucescin and of low molecular weight antibiotics by $S$. glaucescens strain GLA0 in nutrient/glucose broth (open symbols) and in minimal medium (closed symbols). Glaucescin activity $(O, \odot)$ was assayed as 'total antibiotic activity' using $S$. canadiensis strain CAN0 as an indicator. Low molecular weight antibiotics $(\square, \square)$ were measured by the critical dilution assay with $S$. canadiensis strain CAN1 as an indicator. Growth $(\triangle, \boldsymbol{\Delta})$ was followed by measuring the production of cell protein.

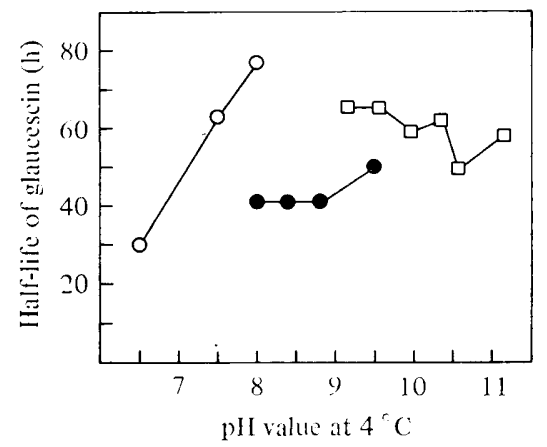

Fig. 4. Stability of glaucescin in different buffers and at different pH values. Portions of an $\left(\mathrm{NH}_{4}\right)_{2} \mathrm{SO}_{4}$ precipitate containing $1024 \mathrm{AU}$ glaucescin $\mathrm{ml}^{-1}$ were dissolved in the buffers, sterilized by filtration and stored at $4^{\circ} \mathrm{C}$. The loss of glaucescin activity was followed over a period of 2 weeks. A linear regression was fitted to a semilogarithmic plot of each decay curve from which the half-life was calculated. Buffers: $0.1 \mathrm{M}$-phosphate $(\bigcirc) ; 0.1 \mathrm{M}-\mathrm{Tris} / \mathrm{HCl}(\mathrm{O}) ; 0.05 \mathrm{M}$-glycine/ $\mathrm{NaOH}(\square)$.

disadvantages of complex media, such as the presence of peptides and melanin formation (Baumann \& Kocher, 1976), minimal medium was used for the production of glaucescin in later experiments. After 30 to $40 \mathrm{~h}$ growth in minimal medium the same glaucescin titres as in nutrient/glucose broth were reached (Fig. 3).

Attempts to induce glaucescin formation by treatment with mitomycin $\mathrm{C}$ failed. Mitomycin $\mathrm{C}$ was added at various concentrations $\left(0.5\right.$ to $\left.8 \mu \mathrm{g} \mathrm{ml}^{-1}\right)$ either early or late during growth of strain GLA0. Although these concentrations of mitomycin $\mathrm{C}$ led to various degrees of inhibition of growth, the glaucescin titres observed during the $12 \mathrm{~h}$ cultivation following addition of the inhibitor were always lower than in the mitomycin $\mathrm{C}$-free control (results not shown). Mahoney (1977) reported that it was not possible to induce bacteriocins from Clostridium perfringens in the continuous presence of mitomycin C. However, when excess mitomycin $\mathrm{C}$ was removed after treatment of the cells, induction of bacteriocins was 


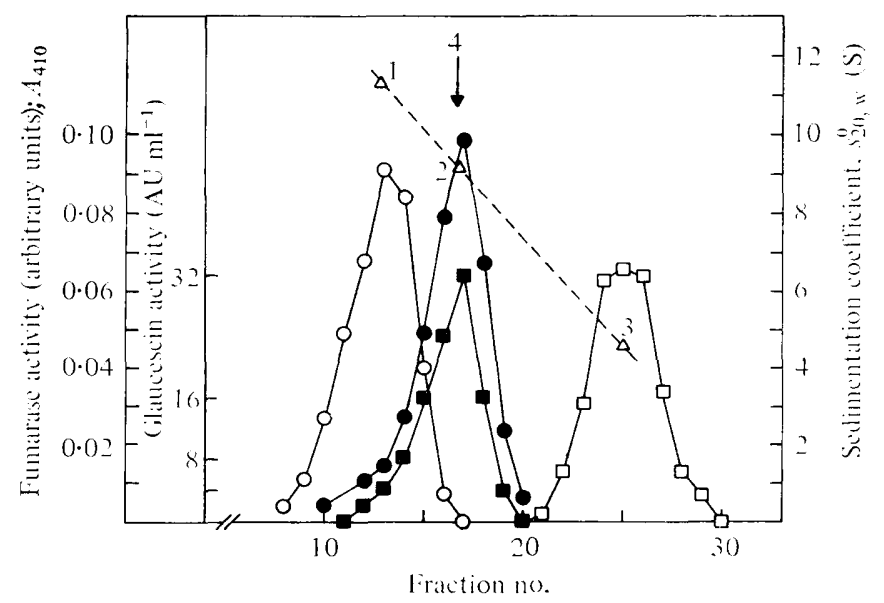

Fig. 5. Centrifugation of glaucescin in a 8 to $33 \%(w / w)$ glycerol gradient: catalase $(0,1)$, fumarase $(\bullet, 2)$, haemoglobin $A(\square, 3)$, glaucescin $(\square, 4)$; sedimentation coefficients $(\triangle)$.

successful. A similar approach was tried for the induction of glaucescin in $S$. glaucescens without success.

\section{Properties of glaucescin}

Glaucescin was unstable at $4{ }^{\circ} \mathrm{C}$. In $0 \cdot 1 \mathrm{M}$-phosphate buffer the stability varied with the $\mathrm{pH}$; at pH 6.5 the half-life was $30 \mathrm{~h}$, while at pH 8.0 it increased to approximately $80 \mathrm{~h}$ (Fig. 4). The stability of glaucescin in $0.1 \mathrm{M}$-Tris $/ \mathrm{HCl}$ buffer and in $0.05 \mathrm{M}$-glycine/ $\mathrm{NaOH}$ buffer was lower at all $\mathrm{pH}$ values tested than its stability in $0 \cdot 1 \mathrm{M}$-phosphate buffer $\mathrm{pH} 8 \cdot 0$ (Fig. 4). Divalent metal ions, protease inhibitors, reducing agents or EDTA had no effect on the stability of glaucescin. However, addition of $20 \%(\mathrm{v} / \mathrm{v})$ glycerol to $0 \cdot 1 \mathrm{M}$-phosphate buffer $\mathrm{pH} 7 \cdot 8$ increased the half-life from 3 to $8.5 \mathrm{~d}$. Glaucescin was thermolabile; a solution in $0 \cdot 1 \mathrm{M}$-phosphate buffer $\mathrm{pH} 7 \cdot 8$ containing $20 \%(\mathrm{v} / \mathrm{v})$ glycerol was completely inactivated by $30 \mathrm{~min}$ incubation at $55^{\circ} \mathrm{C}$ but was unaffected at $40^{\circ} \mathrm{C}$ or below. Chloroform had no influence on glaucescin stability when the preparations were kept at $4^{\circ} \mathrm{C}$. However, freezing in the presence of chloroform led to a rapid inactivation of glaucescin.

To obtain information on the chemical nature of glaucescin, the sensitivity of a concentrated glaucescin preparation to various degrading enzymes was tested. Pronase, proteinase K, trypsin, DNAase 1, RNAase A, and lipase were dissolved at final concentrations of $0.5 \mathrm{mg} \mathrm{ml}^{-1}$ in a solution of glaucescin in $0.1 \mathrm{M}$-phosphate buffer $\mathrm{pH} 7.8$ containing $20 \%(\mathrm{v} / \mathrm{v})$ glycerol. Samples containing lipase and DNAase 1 in addition contained $5 \mathrm{~mm}-\mathrm{MgCl}_{2}$ plus $5 \mathrm{~mm}-\mathrm{NaCl}$ and $5 \mathrm{~mm}-\mathrm{MgCl}_{2}$, respectively. After $1 \mathrm{~h}$ incubation at $30^{\circ} \mathrm{C}$ the glaucescin titres were determined and compared with controls incubated without added enzymes. There was no inactivation of glaucescin by any of the enzymes tested, so that speculations about the chemical composition of glaucescin seem premature.

Estimations of the molecular weight of glaucescin were performed by gel filtration on Sepharose CL-6B and by ultracentrifugation in 8 to $33 \%(\mathrm{w} / \mathrm{w})$ glycerol gradients. Glycerol rather than sucrose was chosen as the medium for the gradients in order to create conditions for maximal stability of glaucescin. Glaucescin activity eluted from Sepharose CL-6B as a single symmetrical peak corresponding to a molecular weight of 196000 . Glaucescin also sedimented as a single band during centrifugation in glycerol gradients (Fig. 5). The shape of the glaucescin peak was similar to the shape of the peaks formed by the marker enzymes, indicating that a single molecular species of glaucescin was present. Maximum activity sedimented at $9 \cdot 28 \mathrm{~S}$ corresponding to an apparent molecular weight of 198000 . 


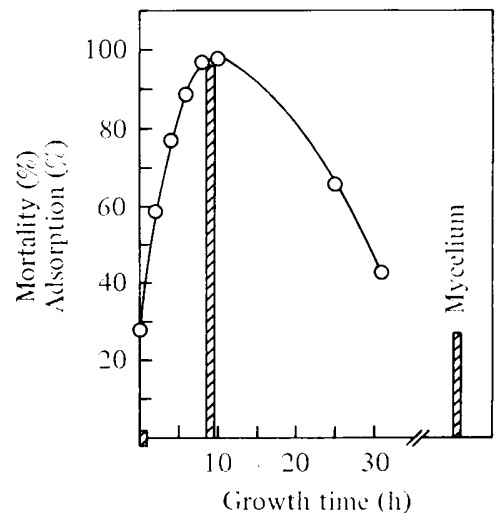

Fig. 6. Sensitivity to glaucescin and adsorption capacity for glaucescin during germination and outgrowth of spores from $S$. canadiensis. For the determination of glaucescin sensitivity $(O)$, nutrient/glucose broth was inoculated with spores of strain CAN0 $\left(10^{4} \mathrm{ml}^{-1}\right)$ and incubated at $30^{\circ} \mathrm{C}$ without agitation. At intervals, $1 \mathrm{ml}$ samples were taken, mixed with $1 \mathrm{ml}$ glaucescin solution $\left(48 \mathrm{AU} \mathrm{ml}^{-1}\right.$ ), incubated for $1 \mathrm{~h}$ at $30^{\circ} \mathrm{C}$, and tested for survivors by plating an appropriate dilution on yeast extract/malt extract agar. As 1 AU glaucescin killed $2 \times 10^{5}$ spores in the standard assay, spores were exposed to a 1000-fold excess of glaucescin in this experiment. For measuring the adsorption of glaucescin $(\square), 2 \times 10^{9}$ spores of strain CAN0 (50 mg wet wt) were suspended in $1 \mathrm{ml}$ nutrient broth and mixed with an equal volume of glaucescin solution (48 $\mathrm{AU} \mathrm{ml}^{-1}$ ). After incubation for $30 \mathrm{~min}$ at $30^{\circ} \mathrm{C}$, the spores were removed by centrifugation and the residual glaucescin activity was measured. The decrease in the glaucescin titre was considered to be due to adsorption. The same procedure was followed with $2 \times 10^{9}$ spores of strain CANO which had been preincubated for $9 \mathrm{~h}$ at $30^{\circ} \mathrm{C} \mathrm{(300} \mathrm{mg} \mathrm{wet} \mathrm{wt)} \mathrm{and} \mathrm{with} \mathrm{mycelium} \mathrm{(300} \mathrm{mg} \mathrm{wet} \mathrm{wt)} \mathrm{grown} \mathrm{for} 41 \mathrm{~h}$ at $30^{\circ} \mathrm{C}$.

\section{Growth phase-dependent glaucescin sensitivity of $S$. canadiensis}

The growth phase-dependent sensitivity of $S$. canadiensis was first observed when indicator plates were used which had been stored for 6 weeks at $4{ }^{\circ} \mathrm{C}$. The spores on these plates had germinated and had become insensitive to a glaucescin solution of $128 \mathrm{AU} \mathrm{ml}^{-1}$. In a subsequent experiment, spores preincubated in nutrient/glucose broth for various times were exposed to a 1000 -fold excess of glaucescin and assayed for survival by plating on yeast extract/malt extract agar. Resting spores were only moderately sensitive to glaucescin (Fig. 6) whereas germinating spores passed through a phase in which $100 \%$ of the population was killed by glaucescin. As outgrowth of the spores continued and mycelium was formed, sensitivity to glaucescin decreased again. In the experiment described in Fig. 6 spore germination was asynchronous. However, as judged from microscopical examinations, the majority of the spores were outgrowing or had finished outgrowth after 8 to $10 \mathrm{~h}$ incubation when the population had reached maximum sensitivity to glaucescin. The adsorption capacity of $S$. canadiensis for glaucescin paralleled the sensitivity to glaucescin. When an excess of resting spores was incubated with a dilute glaucescin solution no binding of glaucescin was detected. Outgrowing spores at the stage of maximum sensitivity adsorbed all glaucescin from the solution while mycelium again showed poor binding capacity (Fig. 6).

Under the same conditions a non spore-forming, glaucescin-insensitive Nocardia mediterranei adsorbed no glaucescin.

\section{Activity spectrum of glaucescin}

A number of Gram-negative and Gram-positive bacteria with special emphasis on representatives of the Actinomycetales were tested for sensitivity to glaucescin: 22 out of 27 streptomycetes species and 5 out of 6 other spore-forming species of different actinomycetes genera showed various degrees of sensitivity as compared with the standard indicator strain $S$. canadiensis (Table 1). The sensitive strains $S$. venezuelae LBG A3015, 


\section{Table 1. Activity spectrum of glaucescin}

Spore suspensions of all spore-forming actinomycetes strains were prepared. Spore titres were determined by viable counts and indicator plates with $10^{7}$ spores per plate were prepared as described for $S$. canadiensis. The Nocardia strains were examined in the same way as the sporeforming actinomycetes. Other bacteria were grown overnight in nutrient/yeast broth and $0 \cdot 1 \mathrm{ml}$ samples of each of these cultures were mixed with $2.5 \mathrm{ml}$ soft agar and poured on yeast extract $/ \mathrm{malt}$ extract plates. The sensitivity against a concentrated glaucescin solution $\left(1024 \mathrm{AU} \mathrm{ml}^{-1}\right)$ was determined with the standard glaucescin assay. Sensitivity is expressed relative to the sensitivity of S. canadiensis, which was set at 1 .

\begin{tabular}{|c|c|c|}
\hline Species & Strain* & $\begin{array}{c}\text { Relative } \\
\text { sensitivity }\end{array}$ \\
\hline Streptomyces lavendulae & ATCC 8664 & 0 \\
\hline S. bikiniensis & ATCC 11062 & 0 \\
\hline S. echinatus & ATCC 19748 & 0 \\
\hline S. longispororuber & ATCC 27443 & 0 \\
\hline S. violaceoruber & DSM 40701 & 0 \\
\hline S. glaucescens & ETH 22794 & 0 \\
\hline S. violaceoniger & Tü 1418 & 0.02 \\
\hline S. arenae & ATCC 25428 & 0.03 \\
\hline S. griseus & IMRU 3495 & 0.05 \\
\hline S. phaeochromogenes & ETH 6282 & $0 \cdot 16$ \\
\hline S. venezuelae & LBG A 3015 & $0 \cdot 16$ \\
\hline S. parvulus & NRRL B-1628 & $0 \cdot 16$ \\
\hline S. violaceoruber $[S$. coelicolor $\mathrm{A} 3(2)]$ & DSM 40783 & $0 \cdot 19$ \\
\hline S. venezuelae & ETH 10933 & $0 \cdot 38$ \\
\hline S. antibioticus & IMRU 9435 & $0 \cdot 75$ \\
\hline S. umbrinus & LBG A 3169 & 0.75 \\
\hline S. viridochromogenes & ATCC 14920 & 1 \\
\hline S. aureofaciens & ETH 13384 & 1 \\
\hline S. canadiensis & NRRL 3155 & 1 \\
\hline S. griseus & NRRL B-1077 & $1 \cdot 3$ \\
\hline S. aureofaciens & ATCC 10762 & $2 \cdot 7$ \\
\hline S. albus & IMRU 3889 & 4 \\
\hline S. hirsutus & ETH 13765 & 8 \\
\hline S. ramulosus & ATCC 19802 & $13 \cdot 3$ \\
\hline S. niveus & NCIB 9219 & 16 \\
\hline S. azureus & ATCC 14921 & 16 \\
\hline S. olivaceus & ATCC 3335 & $21 \cdot 3$ \\
\hline S. coelicolor (Müller) & LBG A 3170 & $21 \cdot 3$ \\
\hline Streptoverticillium griseocarneum & ATCC 12628 & 0 \\
\hline Microellobosporia flavea & ATCC 15839 & 0.004 \\
\hline Micromonospora melanospora & DSM 43126 & $0 \cdot 01$ \\
\hline Streptosporangium roseum & ATCC 12428 & 1 \\
\hline Microellobosporia cinerea & ATCC 15840 & 1 \\
\hline Actinoplanes armeniacus & ATCC 15676 & 8 \\
\hline Nocardia uniformis & DSM 43136 & 0 \\
\hline N. asteroides & NCTC 6761 & 0 \\
\hline N. brasiliensis & IMRU 536 & 0 \\
\hline N. opaca & DSM 43135 & $\mathbf{0}$ \\
\hline N. mediterranei & ATCC 13685 & 0 \\
\hline
\end{tabular}

Insensitive organisms. Gram-negative: Salmonella typhimurium, Pseudomonas aeruginosa, Escherichia coli, Proteus vulgaris, Serratia marcescens, Acinetobacter calcoaceticus. Gram-positive: Staphylococcus aureus, Micrococcus flavus, Sarcina lutea, Lactobacillus plantarum, Bacillus subtilis, B. cereus (cells and spores), B. thuringiensis (cells and spores), Corynebacterium glutamicum, Brevibacterium flavum.

* ATCC, American Type Culture Collection; DSM, Deutsche Sammlung von Mikroorganismen; ETH, Strain collection of the Institute of Microbiology, ETH, CH-8092 Zürich, Switzerland; IMRU, Institute of Microbiology, Rutgers - The State University, New Brunswick, U.S.A.; LBG, Strain collection of the Institute of Microbiology, ETH, CH-8092 Zürich, Switzerland; NCIB, National Collection of Industrial Bacteria; NCTC, National Collection of Type Cultures; NRRL, Northern Regional Research Laboratory; Tü, Prof. Zähner, Institut für Biologie II, Universität Tübingen, F.R.G. 
S. griseus NRRL B-1077 and S. ramulosus ATCC 19802 were tested for sensitivity against high molecular weight substances other than glaucescin which might be present in the glaucescin preparation. Only those fractions from a 8 to $33 \%(w / w)$ glycerol gradient of glaucescin which inhibited $S$. canadiensis were active against the other three strains. It is thus likely that glaucescin represents the only macromolecular inhibitor active against streptomycetes in the preparation used for testing the activity spectrum.

None of five non spore-forming Nocardia species and none of the other bacteria tested, including a Corynebacterium sp. and a Brevibacterium sp., were sensitive to glaucescin. Since glaucescin did not affect endospores of Bacillus species, its activity seems to be restricted to members of the spore-forming Actinomycetales. The producing strain, $S$. glaucescens GLA0, was insensitive to glaucescin.

\section{DISCUSSION}

The scarcity of reports on bacteriocins and bacteriocin-like substances from Streptomyces strains is striking. It probably does not reflect a limited occurrence of bacteriocinogeny in this genus as compared to other genera of Gram-positive bacteria but rather is due to difficulties in detecting macromolecular antagonists of growth with simple screening methods. As illustrated by the system described in this communication, the inhibitory action of bacteriocins from Streptomyces strains on solid media may be masked by fastdiffusing low molecular weight antibiotics. We have eliminated inhibitory activity unrelated to glaucescin by selecting a spontaneous tetracenomycin-resistant derivative of the indicator strain which allowed the demonstration of glaucescin production in cross-streak assays on plates. I. Stevenson \& D. A. Hopwood (personal communication) have made similar observations with coelicin, a bacteriocin from S. coelicolor strain A3(2).

The formation of some bacteriocins from Gram-positive bacteria is critically affected by components of the growth media (Tagg et al., 1976) or requires solid media, as in the case of the bacteriocin from Actinomyces odontolyticus (Franker et al., 1977). The production of glaucescin by $S$. glaucescens was only slightly influenced by such factors. It occurred on solid as well as on liquid minimal and complex media. Efforts to induce glaucescin by exposing a growing culture to mitomycin $\mathrm{C}$ failed. This observation as well as its apparent molecular weight of 196000 make it seem unlikely that glaucescin activity is due to a defective bacteriophage. As stated by Bradley (1967), the molecular weight of bacteriocins resembling bacteriophage components is in the range of several millions.

As glaucescin was insensitive to specific hydrolytic enzymes such as proteinases and lipase $\mathrm{C}$, we lack evidence on the nature of the macromolecules responsible for the bactericidal effect. Some other characteristics of glaucescin are compatible with proteinaceous components being involved in its activity and suggest that glaucescin represents a true bacteriocin or a bacteriolytic enzyme. Its extreme instability over a wide range of $\mathrm{pH}$ values, a property of many bacteriocins, decreased by a factor of three when $20 \%$ glycerol was included in the storage buffer. A stabilizing effect of glycerol on the catalytic activity of enzymes has often been observed and was reported for marcescin, a bacteriocin from Serratia marcescens, by Eichenlaub \& Winkler (1974) and for a yeast killer factor by Ouchi et al. (1978). There was no indication that loss of activity of glaucescin was due to aggregation or disaggregation. The sedimentation profile in a glycerol gradient of an aged, partially inactivated glaucescin preparation was similar to the profile of a fresh preparation.

Glaucescin exclusively killed spore-forming Actinomycetales. Non spore-forming nocardiae were insensitive to glaucescin and, as shown for Nocardia mediterranei, did not adsorb the inhibitor. This narrow spectrum of activity of glaucescin is atypical for bacteriocins from Gram-positive bacteria, which usually act on a wide range of Gram-positive species (Tagg et al., 1976).

Streptomyces glaucescens was insensitive to glaucescin. This is in contrast to $S$. virginiae, the only other bacteriocinogenic Streptomyces described so far, which is killed by its own 
bacteriocin (Roelants \& Naudts, 1964). In the case of some colicins, the insensitivity of the producing organism to its own bacteriocin has been shown to be due to an immunity substance simultaneously produced with the bacteriocin (Bowman et al., 1971).

Glaucescin preferentially killed outgrowing spores of the indicator strain $S$. canadiensis. Resting spores and mycelium were less sensitive to the inhibitor. As the adsorption capacity of the indicator strain for glaucescin increased and decreased in parallel with the sensitivity of the indicator to glaucescin, it seems possible that glaucescin receptors are exposed only during a particular phase of development and that differential adsorption is the reason for the growth phase-dependent sensitivity of $S$. canadiensis. Alternatively, glaucescin might inhibit a specific event during germination and outgrowth of streptomycete spores.

We gratefully acknowledge helpful discussions with Professor R. Hütter and the colleagues from the Streptomycete-Laboratory.

\section{REFERENCES}

ANDREWS, P. (1965). The gel-filtration behaviour of proteins related to their molecular weights over a wide range. Biochemical Journal 96, 595-606.

BAumANN, R. \& Kocher, H. P. (1976). Genetics of Streptomyces glaucescens and regulation of melanin production. In 2nd International Symposium on the Genetics of Industrial Microorganisms, pp. 535-551. Edited by K. D. MacDonald. London: Academic Press.

BaumanN, R., Hütter, R. \& Hopwood, D. A. (1974). Genetic analysis in a melanin-producing streptomycete, Streptomyces glaucescens. Journal of General Microbiology 81, 463-474.

Bergmeyer, H. U. (1974). Methoden der Enzymatischen Analyse, 3rd edn. Weinheim: Verlag Chemie.

Bowman, C. M., Sidikaro, J. \& Nomura, M. (1971). Specific inactivation of ribosomes by colicin E3 in vitro and mechanism of immunity in colicinogenic cell. Nature New Biology 234, 133-137.

BRADLEY, D. E. (1967). Ultrastructure of bacteriophages and bacteriocins. Bacteriological Reviews 31, 230-314.

Eichenlaub, R. \& Winkler, U. (1974). Purification and mode of action of two bacteriocins produced by Serratia marcescens HY. Journal of General Microbiology 83, 83-94.

Franker, C. K., Herbert, C. A. \& Ueda, S. (1977). Bacteriocin from Actinomyces odontolyticus with temperature-dependent killing properties. Antimicrobial Agents and Chemotherapy 12, 410-417.

Ganguly, P., Das Gupta, N. N. \& Chatterjea, J. B. (1963). Sedimentation characteristics of the human haemoglobin A, F and E. Nature, London 199, 919-920.

Goldin, B. R. \& Frieden, C. (1971). L-Glutamate dehydrogenases. Current Topics in Cellular Regulation 4, 77-117.

Herbert, D., Phipps, P. J. \& Strange, R. E. (1971). Chemical analysis of microbial cells. Methods in Microbiology 5B, 209-344.

Hopwood, D. A., Chater, K. F., Dowding, J. E. \& Vivian, A. (1973). Advances in Streptomyces coelicolor genetics. Bacteriological Reviews 37, 371-405.

Hunt, D. E. \& Sandham, H. J. (1969). Improved agar gradient plate technique. Applied Microbiology 17, 329-330.
HÜTTER, R. (1967). Systematik der Streptomyceten. Basel: Karger.

JAENICKE, R. \& KNOF, S. (1968). Molecular weight and quaternary structure of lactic dehydrogenase. European Journal of Biochemistry 4, 157-163.

KanareK, L., Marler, E., Bradshaw, R. A., Fellows, R. E. \& Hill, R. L. (1964). The subunits of fumarase. Journal of Biological Chemistry 239, 4207-4211.

Mahony, D. E. (1977). Induction of bacteriocins from Clostridium perfringens by treatment with mitomycin C. Antimicrobial Agents and Chemotherapy 11, 1067-1068.

Martin, R. G. \& Ames, B. N. (1961). A method for determining the sedimentation behaviour of enzymes: application to protein mixtures. Journal of Biological Chemistry 236, 1372-1379.

Mayr-Harting, A., Hedges, A. J. \& Berkeley, R. C. W. (1972). Methods for studying bacteriocins. Methods in Microbiology 7A, 316-422.

Ouchi, K., Kawase, N., Nakano, S. \& Akiyama, H. (1978). Stabilization of yeast killer factor by glycerol. Agricultural and Biological Chemistry 42, $1-5$.

Pridham, T. G. \& Lyons, A. J. (1961). Streptomyces albus (Rossi Doria) Waksman et Henrici: taxonomic study of strains labelled Streptomyces albus. Journal of Bacteriology 81, 431-441.

Pridham, T. G., Anderson, P., Foley, C., Lindenfelser, L. A., Hesseltine, C. W. \& Benedict, R. G. (1957). A selection of media for maintenance and taxonomic studies of streptomycetes. Antibiotics Annual 1956/57, 947-953.

Roelants, P. \& Naudts, F. (1964). Properties of a bacteriocin-like substance produced by Streptomyces virginiae. Antonie van Leeuwenhoek 30, 45-53.

Sorer, H. A. (1970). Handbook of Biochemistry. Selected Data for Molecular Biology, 2nd edn, pp. C3-C35. Cleveland: The Chemical Rubber Company.

SzYBALSKY, W. (1952). Gradient plate technique for study of bacterial resistance. Science 116, 46-47.

TAGG, J. R., Dajani, A. S. \& WannamaKer, L. W. (1976). Bacteriocins of gram-positive bacteria. Bacteriological Reviews 40, 722-756.

Weber, W., Zaehner, H., Siebers, J., Schroeder, K. 
\& ZEECK, A. (1979). Stoffwechselprodukte von Mikroorganismen, 175. Mitteilung. Tetracenomycin C. Archives of Microbiology 121, 111-116.

Wu, J. \& YANG, J. T. (1970). Physicochemical characterization of citrate synthase and its subunits. Journal of Biological Chemistry 245, 212-218.
Yousten, A. A. \& Rogoff, M. H. (1969). Metabolism of Bacillus thuringiensis in relation to spore and crystal formation. Journal of Bacteriology 100, 1229-1236. 